\title{
THREE CANDIDATE GENES AND ITS ASSOCIATION WITH QUANTITATIVE VARIATION OF EGG PRODUCTION TRAITES OF LOCAL QUAIL BY USING PCR-RFLP
}

L. S. Ahmed*

Lecturer
Y.M.S. AL-Barzinji

Assit. Prof.

Dept. of Animal Resources - Coll. of Agric. Engine. Science -University of Salahaddin-Erbil

Lajan.ahmed@su.edu.krd

\section{ABSTRACT}

The aim of study was to investigate the potential candidate gene $S E M A 3 E, T L X$ and $G H$ and their association with the economic traits, which is becoming increasingly important in poultry breeding program. A total of 72 genomic DNA samples from three female local lines of quail including (desert, brown and white) were collected to determine the association of genes with reproduction trait using PCR-RFLP Technique. According to growth performance the Best Linear Unbiased Prediction (BLUP) value in selected females for high (H) and low (L) production traits was ranged from $\mathbf{- 9 . 2 1 7 3}$ to $\mathbf{0 . 3 8 2 7}$. This value is used to estimate body weight at first egg (BWFE), age at first egg (AFE), weight at first egg (WFE), Egg number per Bird (ENPH), Average egg weight (EWTA), and hen day (HD) in three lines. The results indicate that there was a wide intra specific SEMA3E, TLX and GH variability among these local quails which identifying twelve differences genotypes. The identified genotypes for all genes had a significantly $(\mathrm{P}<0.05)$ affected on the reproduction trait during first 150 days. The quail's genotype AAABAA always exhibited the largest body weight at first egg in desert $H$ line, while $L$ line of white was greater in Egg number per bird and hen day of the genotype ACCCAC. No significant associations were observed between all loci and age at first egg trait among local quails. The results indicate that there are agreements between BLUP values with PCR-RFLP results to achieve a favorable selection response in reproductive performance of local quail in Kurdistan region, Iraqi.

Key words: Local quail, RFLP, Polymorphism, egg production traits.

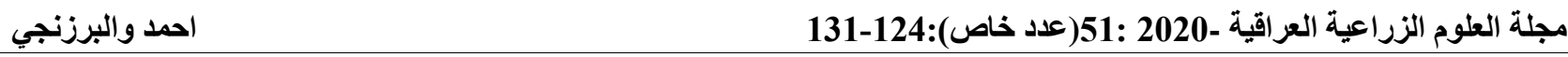

تعدد المظاهر لثثلاث جينات المرشحة وارتباطها بالتباين الكمي لصفات إنتاج البيض من السمان المحلي باستخدام تقتية PCR-RFLP

$$
\text { لاجان صلاح الدين احمد } \quad \text { مدرسف محمد صالح نوري البرزتجي }
$$

$$
\text { قسم الثروة الحيوانية - كلية الزراعة - جامعة صلاح الدين -اريبل }
$$

Lajan.ahmed@su.edu.krd

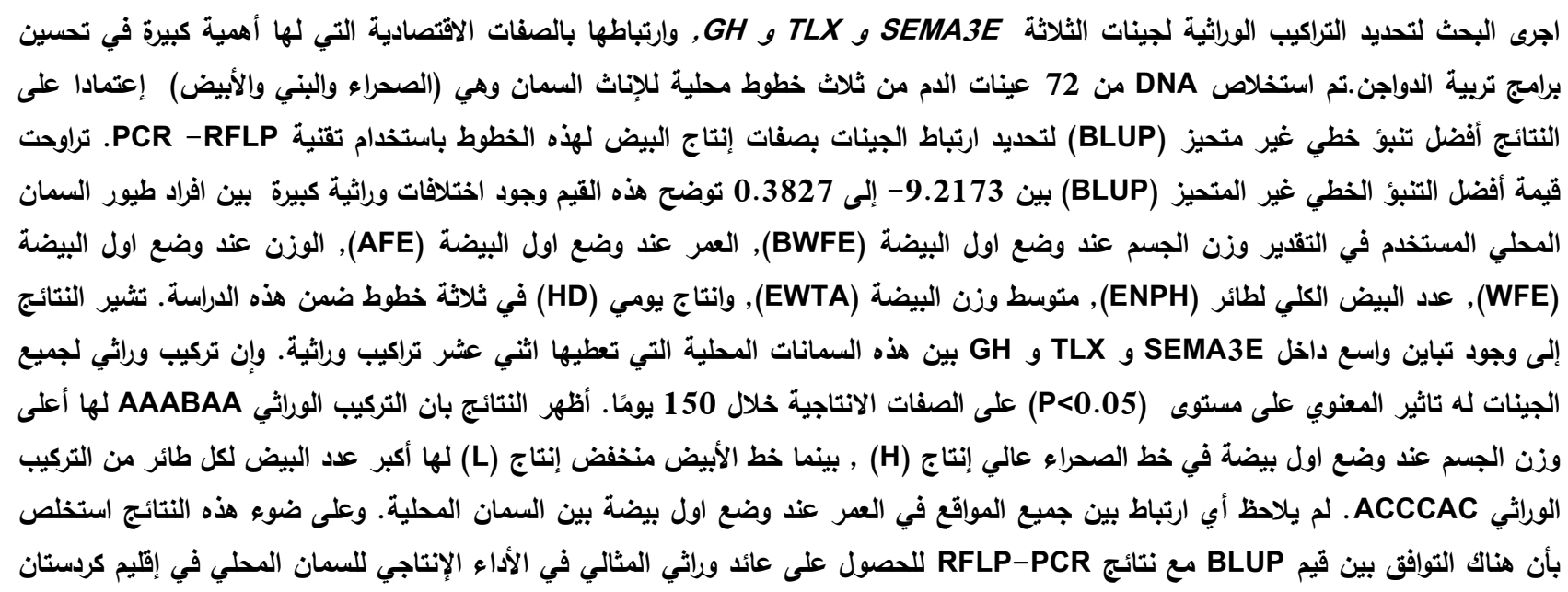




\section{INTRODUCTION}

Quail is one of the poultry species, which have been used in various biological and genetic experiments including meat and egg production. Quail is popular bird model in numerous fields of research because of its small body size, short generation interval (3-4 generation per year), resistance to many common avian disease and high egg production it has been considered as an excellent laboratory experimental bird, less feed and easy maintenance Vali, (29) and Akpa et al., (2). Early sexual maturity quails t the age of six weeks, females start to lay eggs, but their full production usually begin at the age of 50 days (about 7 weeks). Females are averagely lay 300 eggs during their entire reproductive period which generally lasts 1012 months Kayang et al., (13), Chełmońska et al., (7) and Alkan et al., (3). The production of egg is regarded as one of the most performance parameters of laying birds. Despite effective roles of additive genetics on egg production, other factors including age at sexual maturity, bird weight, its nutrition, management and environmental systems might also affect egg production of Japanese quail Daikwo et al., (9). The creation of highperformance lines is the main goal of modern breeding in the poultry industry Kulibaba et al., (16). Such poultry lines have moderately been of importance to both breeders and farmers. Genetic roles have experimentally been confirmed to affect traits that are associated with both production and reproduction King'ori, (14) and Miazi et al., (20). Best Linear Unbiased Prediction (BLUP) has been widely used in genetic evaluation of poultry species Konig et al., (15) and Rozempolska-Rucinska et al., (23). Traditionally, selection of animals for breeding is based on two types of data pedigree and phenotypes. BLUP combines these data to generate estimated of breeding values Baumung et al., (4). DNA based molecular markers for candidate gene studies have been developed and identified for economic traits in several species including poultry. The identification of genetic/ DNA markers and the development of marker assisted selection (MAS) provides an effective approach for genetic improvement programs and enhance- animals ability to adapt to the environment of animals Liu, (18) and Chethan et al., (8) Generally, growth and reproduction of organisms is naturally regulated by growth hormone $(G H)$. This polypeptide component is effectively involved in a wide range of physiological activities such as aging, production of egg, reproduction and also body composition Shaw et al., (27). The GH gene is located on the tip of the long arm of the chromosome 1. Vasilatos-Younken et al., (30)In addition, egg numbers and laying rates are associated with SacI locus which locates in intron 4 of $c G H$ gene Markhous et al,, (19). Moreover, a secreted class 3 semaphorinis encoded by $S E M A 3 E$ gene are specifically involved in the repulsion of endothelial cells of vascular beds. This gene product is also contributed in regulating axonal growth and synaptic connectivity leading to gain an adequate of the central nervous system CNS Cariboni et al., (6). Moreover, Song et al., (28) demonstrated that T-cell leukemia translocation, also known as Hox11 (TLX) is considered as an important target in neural development through the progressive regulation of cell cycle in Neural Stem Cells (NSCs). Modern poultry production is generally aimed at elevation of egg production and inhibition of incubation behavior $\mathrm{Xu}$ et al., (31). Data from this study can be used as basic input for innovative breeding program to select for reproductive traits associated with three candidate genes (SEMA3E, TLX and GH) which plays an essential role in reproduction, metabolism, and regulation of the immune system. It has been reported that the candidate genes such as Growth Hormone affect on reproductive characteristics of quails $\mathrm{Nie} e t$ al., (22), This study was aimed to investigate the variability of three candidate genes and economically importance traits of local quail in Kurdistan region, Iraq using Restriction Fragment Length Polymorphism (RFLP-PCR).

\section{MATERIALS AND METHODS}

\section{Location and morphological measurements}

The experiments were carried out at Grdarasha research center, animal resources department, College of Agriculture, University of Salahaddin. For this purpose 363 newly hatched female chicks of three local lines, 
desert (111), brown (123) and white (125) each line were randomly distributed into ten families; the mating system was in a ratio of one male to three females. The estimated BLUP of $\% 10$ (top and bottom) of three female lines was according to their differences in feather color and body weight. The birds were raised in cages and had free access food and water. The egg production performance of quails were recorded as body weights at first egg (BWFE) in g; Age at first egg (AFE) in days; Mean weight of eggs (MEW) in g 150 days, hen days (HD), weights at first egg (WFE) in $g$ and Egg number per Bird (ENPH) at 150 days of age.

\section{DNA extraction}

Blood samples were collected from each bird after slaughtering and $1 \mathrm{~mL}$ of blood sample was placed in a $3 \mathrm{ml}$ of anti-coagulant Tris-ethylene di amine tetra acetic acid (EDTA) tube and stored at $-20^{\circ} \mathrm{C}$ until DNA extraction. Genome DNA was extracted from the blood using a blood DNA extraction kit (GeNet Bio, korea). Quality and quantity of DNA were examined by Nanodrop (1000 UK) spectrophotometer and gel electrophoresis.

\section{RFLP-PCR}

The final volume of PCR mixture was $25 \mu \mathrm{L}$ composed of $10 \mu \mathrm{L}$ of Green Master Mix $(200 \mu \mathrm{M}$ dNTPs, 25 units $/ \mathrm{mL}$ Taq polymerase and also1.5 $\mathrm{mM} \mathrm{MgCl2}$ ), $1 \mu$ Lfor each forward and reverse primer, $1 \mu \mathrm{L}$ of extracted DNA and the final volume was performed by the addition of $13 \mu \mathrm{L}$ of DNAse free water. Two respective genes (CJA1 and CJA3) were amplified using a particular setting consisted of initial denaturation step at $94^{\circ} \mathrm{C}$ for $5 \mathrm{~min}$ (one cycle), then it is followed by $\left[94^{\circ} \mathrm{C}\right.$ for $1 \mathrm{~min}$, annealing step at $60{ }^{\circ} \mathrm{C}$ for $1 \mathrm{~min}$, and finally $72{ }^{\circ} \mathrm{C}$ for $1 \mathrm{~min}$ (32 cycles)]. These steps are followed by a final extension step $72{ }^{\circ} \mathrm{C}$ for 5 min. The digestion of $10 \mu \mathrm{L}$ of PCR product was made using the restriction enzyme Sasazaki et al., (24) with some minor modifications and also based on the instructions of the manufacturer (Thermo Scientific). This process was investigated by gel electrophoresis preparing $2.5 \%$ of agarose that was stained with $3 \mu \mathrm{L}$ of safe dye (Cat. No. B-2010, GeNet Bio, Korea). The agarose gel was run at a constant voltage of $100 \mathrm{~V} / \mathrm{cm}$ for $45 \mathrm{~min}$. The bands were subsequently visualized by UV transilluminator and the gel photographed (Proxima 2500 Isogene Life science, Netherland).

\section{Statistical analysis}

Genotypes of polymorphic loci were determined by direct counting of the bands. The gene frequencies for each locus in each sample were calculated using the following equations:

$p=\frac{2(A A)+A B}{2 N} \quad q=\frac{2(B B)+A B}{2 N}$

where $p=$ the gene frequency of allele $A, q=$ the gene frequency of allele $\mathrm{B}$ and $\mathrm{N}=$ the total number of birds tested and tested to Hardy-Weinberg ratios using was calculated using GENPOP software version $4.13 \mathrm{Xu}$ et al., (32). The association between genotypes with reproductive traits was investigated using the GLM procedure of SAS software (25) and the genetic effects on average egg weight and total number of eggs laid during first 150 days after flocks maturity (when 5\% of the flock are in egg production) were analyzed by following model:

\section{$\boldsymbol{Y}_{i j k}=\boldsymbol{\mu}+\boldsymbol{G}_{i}+\boldsymbol{H}_{j}+\boldsymbol{E}_{i j k}$}

Where: Yijk= observed trait values at 150 day, $\mu=$ overall means, $\mathrm{Gi}=$ Genotype with a variation for the candidate gene $(i=1-3)$, $\mathrm{Hj}=$ fixed effect of reproductive trait, Eijk=random residual effect. The genotypes effects on reproductive traits were fitted to following equations:

$Y_{i j k l o}=\mu+A_{i}+S_{j}+C_{k}+P_{l}+\varepsilon_{i j k l o}$

Where: $\mathrm{Y}$ ijklo $=$ reproductive traits of $\mathrm{o}^{\text {th }}$ bird, of $\mathrm{i}^{\text {th }} \mathrm{GH}$ (Ai, $\mathrm{i}=1, \mathrm{AC}, \mathrm{i}=2, \mathrm{AB}$ and $\mathrm{i}=3$, $\mathrm{CC}$ ), of $\mathrm{j}^{\text {th }}$ SEMA3E ( $\mathrm{Sj}, \mathrm{j}=1, \mathrm{AB}, \mathrm{j}=2, \mathrm{BC}$ and $\mathrm{j}=3, \mathrm{CC})$, of $\mathrm{k}^{\text {th }} \operatorname{TLX}(\mathrm{Ck}, \mathrm{k}=1, \mathrm{AA}, \mathrm{k}=2$, $\mathrm{AB}$, and $\mathrm{k}=3, \mathrm{AC})$, of $1^{\text {th }}$ all genes combinations $\quad(\mathrm{Pl}, \quad \mathrm{l}=1$ ,2,3,4,5,6,7,8,9,10,11, and 12), $\mu=$ Population mean, $\boldsymbol{E}_{i j k l o}=$ random error. It was assumed to be normally and independently distributed with mean zero and variance $\delta^{2} e$.

For genetics evaluation of bird for various performance traits, Best Linear Unbiased Prediction (BLUP) procedure described by SAS, (25) was applied. The model used for this purpose was the Mixed Model (fixed + random effects) of SAS, (25) software. 
Table 1. primer sequences, restriction enzyme used in this study

\begin{tabular}{|c|c|c|c|c|c|}
\hline Gene & Primer Sequence (5'-3') & $\mathrm{Ta}\left({ }^{\circ} \mathrm{C}\right)$ & Enzyme & PCR-RFLP size (bp) & References \\
\hline $\begin{array}{c}\text { SEMA3 } \\
E\end{array}$ & $\begin{array}{c}\text { F:ATACTCCAGCTGAGTGGGGA } \\
\text { R:CAGAAGTATGAGGGAGATCAG }\end{array}$ & 60 & Hae III & $412 / 362+50 / 335+77$ & Sasazaki et al., 2006 \\
\hline$T L X$ & $\begin{array}{c}\text { ACACTAGGAACATAATGGGCT } \\
\text { RTCACTGTGGCGTTTCAGATT }\end{array}$ & 60 & PstI & $546 / 404+142$ & Sasazaki et al., 2006 \\
\hline GH & $\begin{array}{c}F: A T C C C C A G G C A A A C A T C C T C G \\
\quad: C C T C G A C A T C C A G C T C A C A T\end{array}$ & 56 & Msp 1 & $776 / 529+241$ & Setiati et al., 2014 \\
\hline
\end{tabular}

F: Forward primer; R: Reverse primer; Ta: of Japanese quails. Out of the eight loci Annealing temperature

\section{RESULTS AND DISCUSSION}

The estimated Best Linear Unbiased Prediction (BLUP) value of local quail according to high $(\mathrm{H})$ and low $(\mathrm{L})$ body weight was ranged from ( -8.6613 to $-1.6933 \mathrm{~g}$, 9.2173 to $-2.4293 \mathrm{~g}$ and -4.3113 to 0.3827 ) females of desert, brown and white, respectively at six month. These results indicated that there are big genetic variations among quails for reproductive trait. It means that selection can play a big role in improving egg production trait.

\section{Gene Polymorphism Detection}

The fragment sequences amplified with three primers of (SEMA3E, TLX, and GH) genes were expressed differently and the restriction enzymes cut the gene in different locations in three different lines of local quail are shown in Fig. 2. The RFLP pattern of SEMA3E locus observed three different alleles (A, B and C) and three genotypes $(\mathrm{AB}, \mathrm{BC}$ and $\mathrm{CC})$, while three different alleles (A, $B$ and $C)$ and three genotypes (AA, $\mathrm{AB}$ and $\mathrm{AC}$ ) were found for the TLX locus. Also, GH locus produces two kinds of alleles (A and $\mathrm{C}$ ) with three genotypes (AA, AC and CC). Polymorphisms SEMA3E/ Hae III gene is indicated two bands: $412 \mathrm{bp}$ and $362 \mathrm{bp}$ for $\mathrm{AB}$ genotype, two bands: 362 bp and 50 bp for BC genotype, and two bands: $335 \mathrm{bp}$ and $77 \mathrm{bp}$ for CC genotype. For the TLX/ PstI gene were obtained a single bands $546 \mathrm{bp}$ for the AA genotype, 518bp, 404bp and $142 \mathrm{bp}$ for AC genotype, While the obtained one fragment from GH/MspI was 776bp for the AA genotype, 776bp, 529bp and $241 \mathrm{bp}$ for AC genotype ,and 529bp and 241bp for the AC genotype. In agreement with Bozkaya et al. (5) who describe the possibility of using SEMA3E and TLX loci for studying recombination frequencies in the populations (SEMA3E, IFR1, HAL, LOC396025, UGP2, LOC396192, TLX and BMP5), polymorphism was detected in the SEMA3E and TLX loci; five loci were found to be monomorphic and one locus (HAL) could not be amplified by PCR -RFLP. Similar results were previously reported by Deef, (11) which was performed PCR-RFLP in terms of revealing the genetic characterization and also genetic relationship of the five species of quails. The Common quails are found to be Coturnix coturnix, bobwhite quail Colinus virginianus, and three quails belong to Coturnix japonica including panda quail, japanese quail, dotted white quail. Highly polymorphic restriction profiles were recorded from the analysis of fragments that were generated by digestion of PCR products with the restriction enzyme NlaIII. A wide variability in intra specific COI, SEMA3E and $T L X$ genes was obtained among the respective quails. Also, another study discovered that the genetic characterization and relationships between divergence levels of chicken lines as Red Junglefowl (Gallus gallus gallus) and commercial chicken lines (Gallus gallus domesticus) by using PCR-RFLP technique for five genes (COL1, SEMA3E, TLX, COL2 and COL3). The results showed that there is a wide intraspecific COI (Cytochrom Oxidas I), SEMA3E (Semaphorin-3E) and NR2E1 (TLX) (Nuclear receptor subfamily 2 group $E$ member 1) defrentional among these chicken lines with restriction enzymes NlaIII where this enzyme produced polymorphic intra specific and intere specific restriction fragments in white, Red and Sasso broilers and without any fragments in Red Jungle fowl except COL2 and COL3 primers Deef and ElNabi, (10). 

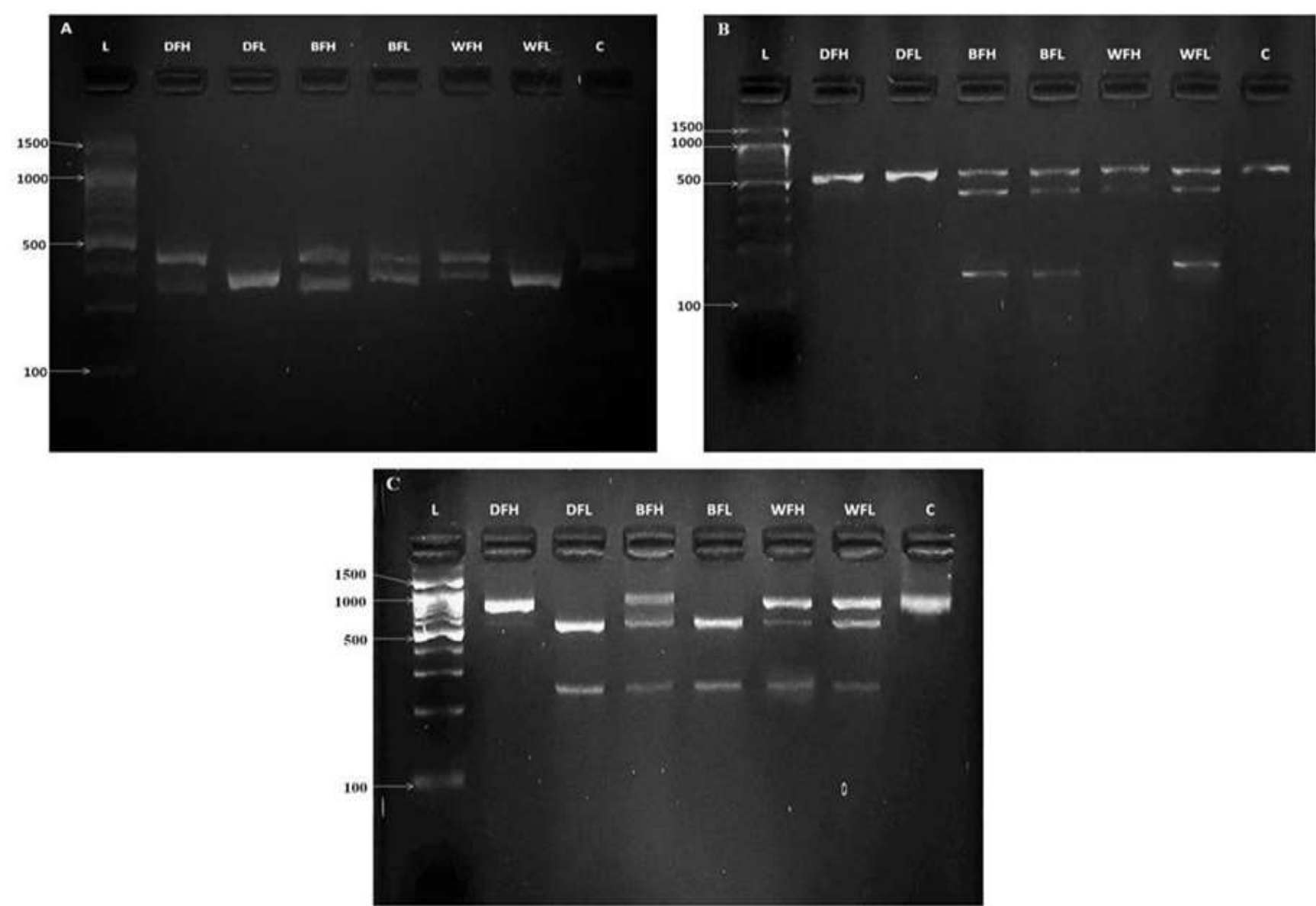

Fig 1. Digestion of PCR products of A) SEMA3E; B) TLX and C) GH of pulled samples in three local lines. L: DNA marker, DFH: desert female high production, DFL: desert female low production, BFH: brown female high production, BFL: brown female low production,

WFH: white female high production and WFL: white female low production.

Allele and genotype frequency in local quail populations

The electrophoresis results of PCR-RFLP analysis products that were digested with restriction enzymes are shown in table 2. For SEMA3E and GH loci, allele $\mathrm{C}$ was the most frequent allele and ranged from 0.583 to 0.542 , while allele $\mathrm{A}$ was identified as a dominant allele in TLX locus due to the highest frequency (0.708). Whereas, the frequency of allele B was higher in SEMA3E (0.333) than TLX (0.083) loci. The frequency of $A B$ heterozygous genotype was the lowest (0.113) in SEMA3E and (0.143) TLX loci but the highest frequency of $\mathrm{BC}$ genotype was

Table 2. Genotypic and allelic frequencies of SEMA3E, TLX and GH genes

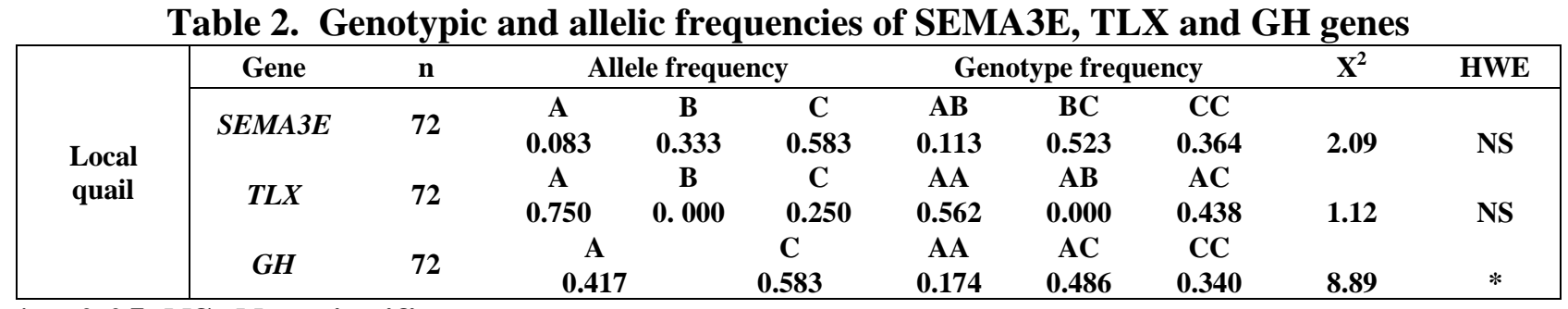

*p<0.05, NS: Non-significant
(0.523). The probability of random mating in the population was estimated by Chi-square $(\chi 2)$ test to examine Hardy-Weinberg equilibrium (HWE) at each locus. The analysis of chi-square test showed that GH loci in (HWE) Hardy-Weinberg equilibrium, while both TLX and SEMA3E loci were not in Hardy-Weinberg equilibrium (Table 2). This is in agreement with the report by Nasirifar et al., (21) showed that the genetic variability in growth hormone association with quantitative variation of live weight, carcass traits in Japanese quail, the population was under the Hardy-Weinberg equilibrium $(\mathrm{P}<0.005)$. 


\section{Genotypes association with egg production traits in local quails}

The analysis results of association between the three (SEMA3E, TLX and GH) genes polymorphisms and egg production traits of three local quail lines are shown in Table 3. In accordance to the genotype for all genes in present study showed a significant association with the egg production traits of local quails in 150 days of lying $(\mathrm{P}<0.05)$. The highest BWFE was (221.74 \pm 3.187$)$ reported in desert $\mathrm{H}$ line in AAABAA genotype but lower in WFE (8.33 \pm 0.577$)$ and EWTA (13.19 \pm 0.853$)$ than $\mathrm{H}$ line of white population with genotype ACBCAA, while L line was greater in ENPB $(121.94 \pm 1.453)$ and HD $(83.77 \pm 1.714)$ of the genotype ACCCAC $(\mathrm{P}<0.05)$. Likewise, for the $\mathrm{H}$ line in the brown population of the genotype CCBCAC was $(38.33 \pm 1.528)$ higher in AFE than desert and white population. Obviously, the genotype for all genes had positive effects on egg production traits in the $\mathrm{H}$ and $\mathrm{L}$ lines among local quails in our experiments. The association of these genes with egg reproduction traits in local quail was also observed by Setiati et al., (26) .who found the effect of divergent selection of high and low weights of the egg production of quail egg traits (Coturnix coturnix japonica) to identify gene polymorphisms $G H$ for six generations which showed variance between high and low due to selection in earlier generations $(\mathrm{P}<$ 0.05), higher weight groups where egg production is lower compared with the low weight group. Lan et al., (17) was studied the effect of growth hormone $(G H)$ polymorphisms in egg production of Japanese quails detected that the polymorphic sites were no significant effect on egg production and egg numbers. Doan et al., (12) showed that the average egg weights were 11.2 and $11.7 \mathrm{~g}$ of Japanese quails, respectively. Makhsousi et al., (17) studied growth hormone polymorphism in a native chicken population and the results showed molecular marker association with laying performance has a significant effective on breeding programmers. It can conclude that the SEMA3E, TLX and $G H$ loci has been shown to be effective marker associations with reproductive performance of local quail lines, in which, AAABAA genotype for all genes are significantly associated with body weight at first egg in desert lines and higher value of egg number per bird. Also the average egg weights at 150 days of age and hen day were higher in genotype ACCCAC in white lines. Evidently, there were no significant differences among the different genotype and lines of age at first egg. And the brown line means tended to be closer to the desert line than the white line for all traits but different from age at first egg and weight at first egg of two lines. This study opens interesting prospects for selection programs in future, particularly marker assisted selection process (MAS).

Table 3. Relationship between genotype of all genes and egg production trait in local quails.

\begin{tabular}{|c|c|c|c|c|c|c|c|c|}
\hline \multirow{2}{*}{ Population } & \multirow{2}{*}{ line } & \multirow{2}{*}{$\begin{array}{l}\text { Genotype } \\
\text { all genes }\end{array}$} & \multicolumn{6}{|c|}{ Association of genes with egg production traits } \\
\hline & & & BWFE & AFE & WFE & ENPB & EWTA & HD \\
\hline \multirow{2}{*}{ Desert } & $\mathbf{H}$ & & $221.74 \pm 3.187^{\mathrm{a}}$ & $39.67 \pm 0.577^{\mathrm{a}}$ & $8.00 \pm 0.000^{\mathrm{ab}}$ & $114.44 \pm 1.638^{d}$ & $12.76 \pm 0.524^{b}$ & $78.34 \pm 2.694^{c}$ \\
\hline & $\mathbf{L}$ & & $192.16 \pm 2.702^{c}$ & $39.67 \pm 0.557^{\mathrm{a}}$ & $.577^{\mathrm{abc}}$ & $317^{\text {bc }}$ & $12.37 \pm 0.380 c^{d}$ & $80.79 \pm 1.248^{b}$ \\
\hline \multirow{2}{*}{ Brown } & $\mathbf{H}$ & ACBCAC & $206.00 \pm 2.745^{b}$ & $38.33 \pm 1.528^{\mathrm{a}}$ & $7.67 \pm 0.577^{\mathrm{ab}}$ & $111.64 \pm 1.861^{\mathrm{e}}$ & $12.62 \pm 0.333^{\mathrm{bc}}$ & $76.37 \pm 1.239^{d}$ \\
\hline & $\mathbf{L}$ & ССВCAC & $180.02 \pm$ & $38.67 \pm 0.577^{a}$ & $6.33 \pm 0.577^{c}$ & 115.85 & $11.92 \pm 0.415^{\mathrm{e}}$ & $80.57 \pm 1.679^{b}$ \\
\hline \multirow{2}{*}{ White } & $\mathbf{H}$ & ACBCAA & $199.91 \pm 2.621^{b}$ & $39.00 \pm 1.732^{\mathrm{a}}$ & $8.33 \pm 0.577^{\mathrm{a}}$ & $117.85 \pm 2.031^{b}$ & $13.19 \pm 0.853^{a}$ & $79.82 \pm 1.180^{b c}$ \\
\hline & $\mathbf{L}$ & ACCCAC & $177.62 \pm 2.447^{d}$ & $39.33 \pm 2.082^{a}$ & $7.00 \pm 1.000^{b c}$ & $121.94 \pm 1.453^{a}$ & $12.18 \pm 0.322^{\text {de }}$ & $83.77 \pm 1.714^{\mathrm{a}}$ \\
\hline
\end{tabular}

Data are expressed as means \pm SE. BWFE = body weight at first egg; AFE = age at first egg; WFE = weight at first egg; ENPH = Egg number per Bird at 150 days of age; EWTA =Average egg weight at 150 days of age; HD= hen day. Different letters in each column represent significant difference according to Duncan multiple range test, $(\mathbf{P}<0.05), \mathbf{n = 7 2}$.

\section{REFERENCES}

1. Ajay-Kumar, A.S.B., M.M. Verma, and K.G, Mandal, 2000. Effect of sex on body weight and conformation traits in selected and control lines of Japanese quail. Indian Vet. J. 77: 325-327

2. Akpa G.N., J.Kaye, I.A. Adeyinka, and M. Kabir, 2008. The relationships between laying age and repeatability of egg quality traits in
Japanese quails (Coturnix coturnix japonica). Int. J. of Poult. Sci. 7(6): 555-559

3. Alkan, S., K. Karabag, A. Galic, T.Karsli, and M.S. Balcioglu, 2010. Farklı hatlardaki Japon bildırcinlarında (Coturnix coturnix japonica) canlı ağırlık ve bazı karkas ozelliklerinin belirlenmesi. Kafkas Univ. Vet. Fak. Derg. 16: 277-280 
4. Baumung, R., H.H.Simianer, and I.Hoffmann, 2004. Genetic diversity studies in farm animals - a survey. J. Anim. Breed. Genet. 121: 361-373

5. Bozkaya, F., Ş. Gurler, and M. Yerturk, 2013. Investigation on the Polymorphism of Some loci by using PCR-RFLP in Japanese quails (Coturnix coturnix japonica) raised in different locations of Turkey. Kafkas Univ. Vet. Fak. Derg. 19: 761-766

6. Cariboni, A., V. André, S. Chauvet, D. Cassatella, K. Davidson, A.Caramello, A. Fantin, P. Bouloux, F.Mann, and C.Ruhrberg, 2015. Dysfunctional SEMA3E signaling underlies gonadotropin-releasing hormone neuron deficiency in Kallmann syndrome. J. Clin. Invest. 125:2413-2428.

7. Chełmońska, B., A. Jerysz, E. Łukaszewicz, A. Kowalczyk, and I. Malecki, 2008. Semen collection from Japanese quail (Coturnix coturnix japonica) using a teaser female. Turkish J. Vet. Anim. Sci. 32:19-24

8. Chethan, R. R, K. Kanaka, C, Jeevan, A.R. Sahu, S. Balraj, S.Dhanpal , and T. Mitek, 2018. A review on polymorphism in egg production linked genes in poultry. J. Entomo. Zoo.Studies. 6(5): 2342-2345

9. Daikwo, S.I., N.I. Dim, and O.M. Momoh, 2014. Genetic parameters of some Egg Production traits in Japanese quail in a tropical Environment. IOSR J. Agric. Vet. Sci. 7(9): 39-42.

10. Deef, L.E.M, 2017. Detection of Genetic Relationship in the Tree of Life of Some Quail Through Molecular Markers Analyses. Braz. Arch. Biol. Technol. 60:1-8

11. Deef, L.E.M, and S.E.H. El-Nabi, 2015. Genetic characterization of Red Junglefowl (Gallus gallus gallus) and commercial chicken lines (Gallus gallus domesticus) using molecular markers. Int. J. Adv Res. 3(10):1763-1769

12. Doan, B.H, and H.Thanh, 2010. Evaluation of Japanese quail production under household condition in $\mathrm{Tu}$ Son - Bac Ninh (In Vietnamese). J. Sci. Devel. 8: 59-67

13. Kayang, B.B, A.Vignal, M. InoueMurayama, M. Miwa, L. Monvoisin, and S. Ito, 2004. A first-generation microsatellite linkage map of the Japanese quail. Anim. Genet. 35: 195-200
14. King'ori, A.M, 2011. Review of the factors that influence egg fertility and hatchabilty in poultry. Int. J. Poult. Sci. 10: 483-492.

15. Konig, S., F.Tsehay, F. Sitzenstock, U.U. Von Borstel, M. Schmutz, R. Preisinger, and H. Simianer, 2010. Evaluation of inbreeding in laying hens by applying optimum genetic contribution and gene flow theory. Poult. Sci. 89:658-667.

16. Kulibaba, R. A, and P. Podstreshnyi, 2012. Prolactin and growth hormone gene polymorphisms in chicken lines of Ukrainian selection. Cytol. Genet. 46: 390-395

17. Lan, L.T.T., T. H. N. Nguyen, T. N. Dinh, T. T. Tran, H. A. Luu, H.X.Nguyen, and T.N. Nguyen , 2017. Association analysis of candidate gene polymorphisms with egg production in Japanese quails ( Coturnix japonica ). Chiang Mai Vet. J. 15(2): 117 -125 18. 18. Liu, Z, 2007. Aquaculture genome technologies. Wiley- Blackwell, Ames, Iowa. 16:369-371

19. Makhsous, S. G., S. Z. Mirhoseini, M. J. Zamiri, and A. Niazi, 2013. Polymorphisms of growth hormone gene in a native chicken population: association with egg production. Bull Vet Inst Pulawy. 57(1):73-77

20. Miazi, O.F., G. Miah, and M.M. Miazi, 2012. Fertility and hatchability of Fayoumi and Sonali chicks. Scholarly J. Agr. Sci. 2(5): 83-86

21. Nasirifar, E., M.Talebi, A. Esmailizadeh, N. Askari, S.S. Sohrabi, and H. Moradian, 2018. Genetic variability in growth hormone gene and association between restriction fragment length polymorphisms (RFLP) patterns and quantitative variation of live weight, carcass, behaviour, heterophil and lymphocyte traits in Japanese quails. Iran. J. Appl. Anim. Sci. 8: 147-152

22. Nie, Q., B. Sun, D. Zhang, C. Luo, N.A. Ishag, M. Lei, G. Yang, and X. Zhang, 2005. High diversity of the chicken growth hormone gene and effects on growth and carcass traits. J. Hered. 96:698-703.

23. Rozempolska-Rucinska, I., G. Zieba, and M. Lukaszewicz. 2013. Her- itability of individual egg hatching success versus hen hatchability in layers. Poult. Sci. 92:321-324

24. Sasazaki, S., T. Hinenoya, B. Lin, A. Fujiwara, and H. Mannen, 2006. A comparative map of macrochromosomes 
between chicken and Japanese quail based on orthologous genes. Anim. Genet. 37, 316-320 25. SAS, Statistical Analyses System, 2004. user's guide: statistics 8 . $6^{\text {th }}$. SAS's Institute Inc. carry, North Carolina USA

26. Setiati, N., T.Widianti, and D. Mustikaningtyas, 2014. Effect of divergent selection body weight to egg production during the six generation and $G H$ gene polymorphism quail (Coturnix co- turnix japonica). in Proc 4th Int. Conf. Math. Sci. Educ. Yogyakarta, Indonesia. 123-128

27. Shaw, J.A., P.C. Mol, B. Bowers, S.J. Silverman, M.H. Valdivieso, A. Durdn, and E. Cabib, 1991. The function of chitin synthases 2 and 3 in the saccharomyces cerevisiae cell cycle. The Journal of Cell Biology. 114(1): 111-123

28. Song, J., K. J. Cho, Y.Oh, J.E. Lee, 2015. Let7a involves in neural stem cell differentiation relating with $T L X$ level.
Biochem. Biophys. Res. Commun. 462:396401.

29. Vali, N., M. Edriss, and H. Moshtaghi, 2006. Comparison of egg weight between two quail strains. Int. J. Poult. Sci. 5:398-400

30. Vasilatos-Younken, R., X. H. Wang, Y. Zhou, J.R. Day, J.P. McMurtry, R.W. Rosebrough, E. Decuypere, N. Buys, V. Darras, and J.I. Beard, 1999. New insights into the mechanism and actions of growth hormone $(G H)$ in poultry. Domest. Anim. Endocrinol. 17: $181-190$

31. Xu, H., X. Shen, M. Zhou, M. Fang, H. Zeng, Q. Nie, X. Zhang, 2010. The genetic effects of the dopamine D1 receptor gene on chicken egg production and broodiness traits. BMC Genet. 11:1-10

32. Xu, H., H. Zeng, C. Luo, D. Zhang, Q. Wang, L. Sun, L. Yang, M. Zhou, 2011. Genetic effects of polymorphisms in candidate genes and the QTL region on chicken age at first egg. BMC Genet. 12-33. 